\title{
Examination of the direct effects of metabolic factors on somatotrope function in a non-human primate model, Papio anubis
}

\author{
Raul M Luque ${ }^{1,2}$, Manuel D Gahete ${ }^{1,2}$, Rudy J Valentine ${ }^{1,2}$ and Rhonda D Kineman ${ }^{1,2}$ \\ ${ }^{1}$ Section of Endocrinology and Metabolism Department of Medicine, University of Illinois at Chicago, Chicago, Illinois, USA \\ ${ }^{2}$ Research and Development Division, Jesse Brown VA Medical Center, M.P 151, West Side, Suite \#6215, 820 South Damen Ave., Chicago, Illinois 60612, USA
}

(Requests for offprints should be addressed to R D Kineman at second address; Email: kineman@ uic.edu)

\begin{abstract}
In humans, circulating GH levels are increased in catabolic states and suppressed in obesity. In both extremes, normalization of the metabolic environment normalizes $\mathrm{GH}$ release, leading to the conclusion that changes in metabolic hormones and/or metabolites promote changes in $\mathrm{GH}$ synthesis and release. Metabolic regulation of $\mathrm{GH}$ secretion can be mediated centrally by modulation of hypothalamic GHRH and somatostatin input to the pituitary and/or by direct regulation of pituitary somatotrope function. Although data are available showing glucocorticoids, free fatty acids (FFA), IGF-I, and insulin have direct effects on rat somatotrope function, little information is available regarding the direct pituitary effects of these metabolic factors in primates. Therefore, this study examined the effects of glucocorticoids (dexamethasone (0.1-100 nM) and hydrocortisone (10 nM)), FFA (oleic and linoleic acid, 100 and $400 \mu \mathrm{M}$ each), IGF-I (0.5-50 nM), and insulin (0.5-50 nM) on GH release and GH, GHRH-receptor (GHRH-R) and ghrelin-receptor (GHS-R) mRNA levels, in primary pituitary cell cultures of baboons (Papio anubis) after $24 \mathrm{~h}$ treatment. A commercial ELISA kit was used to determine the amount of $\mathrm{GH}$ released into the media, while quantitative real-time reverse transcription-PCR was used to determine mRNA levels. To design species-specific primers for baboon $\mathrm{GH}, \mathrm{GHRH}-\mathrm{R}$, GHS-R, insulin receptor (INSR), IGF-I receptor (IGF-IR), pituitary-specific transcription factor-1 (Pit-1), and cyclophilin A (used as a housekeeping gene) CDNA, sequence data for each baboon transcript were obtained and this data were submitted to Genbank. Glucocorticoids, FFA, insulin and IGF-I treatment did not significantly alter the expression of Pit-1, a transcription factor essential for normal somatotrope development and function. However, as previously reported in the rat, glucocorticoids increased, while FFA, IGF-I and insulin decreased GH release in baboon pituitary cell cultures, where changes in $\mathrm{GH}$ release were reflected by comparable changes in $\mathrm{GH}$ mRNA levels. In addition, glucocorticoids increased, while FFA, IGF-I and insulin decreased the expression of the GH stimulatory receptors, GHRH-R and GHS-R, without significantly altering cyclophilin A mRNA levels. A role of insulin/INSR pathway, independent of IGF-I, in regulating pituitary function is supported by the fact that (1) IGF-I and insulin significantly suppressed somatotrope function at doses ( 0.5 and $5 \mathrm{nM}$ respectively) not anticipated to activate their respective receptors, and (2) the baboon pituitary expresses INSR mRNA at levels comparable to or greater than that of tissues commonly considered as insulin sensitive (i.e. liver, skeletal muscle, and fat). Taken together, these results demonstrate that metabolic factors can directly modulate primate somatotrope function through regulating GH synthesis and release, as well as mediating the expression of receptors important in central $(\mathrm{GHRH})$ and systemic (ghrelin) regulation of $\mathrm{GH}$ secretion.
\end{abstract}

Journal of Molecular Endocrinology (2006) 37, 25-38

\section{Introduction}

Changes in the metabolic milieu have a profound impact on circulating growth hormone $(\mathrm{GH})$ levels. In humans, circulating GH levels are increased in catabolic states such as fasting, anorexia and diabetes type I (Ho et al. 1988, Mercado \& Baumann 1995, Scacchi et al. 2003), while basal and stimulated GH release is suppressed in obesity (Maccario et al. 1994, Scacchi et al. 1999, Weltman et al. 2001). Several hypotheses have been put forward regarding how changes in metabolism may alter GH secretion. Many are based on metabolic factors working centrally to alter
GH-releasing hormone (GHRH) or somatostatin (SST) input to the pituitary, resulting in secondary changes in GH synthesis and release. It has also been hypothesized that systemic alterations in metabolic hormones and metabolites can directly impact somatotrope function. Limited studies have been conducted examining the direct metabolic modulation of primate (human) pituitaries, where the majority are confined to studies involving GH-producing adenomas or fetal pituitaries (Oosterom et al. 1984, Nakagawa et al. 1985, Goodyer et al. 1986, Yamashita et al. 1986, Isaacs et al. 1987, Lloyd et al. 1993). The bulk of the knowledge regarding direct metabolic regulation of normal, mature somatotrope 
function is based on studies using primary pituitary cell cultures from adult male rats. These studies have shown: (1) glucocorticoids enhance GH, GHRHreceptor (GHRH-R) and ghrelin receptor (GHS-R) expression (Martinoli et al. 1991, Tamaki et al. 1996, Miller \& Mayo 1997, Tamura et al. 2000), (2) free fatty acids (FFA) block in vitro GH release (Casanueva et al. 1987, Kennedy et al. 1994, Pérez et al. 1997), (3) insulin-like growth factor I (IGF-I) suppresses basal and GHRH-stimulated GH release and GH, GHRH-R and GHS-R mRNA levels (Yamashita \& Melmed 1986c, 1987, Morita et al. 1987, Melmed et al. 1996, Sugihara et al. 1999, Kamegai et al. 2005), and (4) insulin directly decreases GH release and GH mRNA levels (Yamashita \& Melmed 1986a,b, Yamashita \& Melmed 1987).

Although in vitro studies using rat pituitary tissue have yielded invaluable information regarding metabolic regulation of somatotrope function, it has been clearly established that the in vivo effects of metabolic manipulation differ in rats and humans with respect to the GH axis. Specifically, fasting and insulin-induced hypoglycemia suppresses circulating GH levels in the rat (Tannenbaum et al. 1976, 1979), a response opposite to that observed in humans (Ho et al. 1988). Given these caveats, it is not clear if direct metabolic regulation of somatotrope function observed in the rat accurately reflects the impact of these factors on somatotrope function in the primate. To begin to address this issue, primary pituitary cell cultures from normal adult baboons (Papio anubis) were used to examine the direct effects of glucocorticoids (dexamethasone (DEX) and hydrocortisone (HY)), FFA (oleic and linoleic), IGF-I and insulin on basal GH release and GH, GHRH-R and GHS-R mRNA levels.

\section{Materials and methods}

\section{Animals and primary pituitary cell cultures}

Pituitaries were obtained from randomly cyclic female baboons ( $P$. anubis, 15-25 years of age) within $15 \mathrm{~min}$ after sodium pentobarbital overdose. The baboons used represent control animals from the breeding colony which were in studies approved by the University of Illinois at Chicago Institutional Animal Care and Use Committee. Pituitaries were enzymatically dispersed into single cells as previously described (Aleppo et al. 1997) with the exception that each baboon pituitary was dispersed in a siliconized spinner flask (1 pituitary/ $30 \mathrm{ml}$ digestion media per flask), with a single pituitary yielding $\sim 25 \times 10^{6}$ cells with $>98 \%$ viability, as determined by the trypan blue dye exclusion method. Cells were plated at $2 \times 10^{5}$ cells/well in $0.5 \mathrm{ml}$ of a basic media comprised of $\alpha$-minimum essential medium (AMEM) (Invitrogen), $0 \cdot 15 \%$ BSA (Sigma, Cat. A-7906),
$6 \mathrm{mM}$ N-2-hydroxethylpiperazine-N'-2-ethane sulfonic acid (HEPES), $10 \mathrm{UI} / \mathrm{ml}$ penicillin and $10 \mu \mathrm{g} / \mathrm{ml}$ streptomycin (Invitrogen).

\section{Experiment 1}

For studies examining the direct effects of glucocorticoids, cells were subsequently cultured in media containing 10\% horse serum (HS) (Sigma, Cat. H-1138). After a 48-h incubation, cultures were rinsed in serum-free media and incubated for $1 \mathrm{~h}$ and the media was then replaced with serum-free media containing $0,0 \cdot 1,1,5,10$ or 100 nM DEX (Sigma, Cat. D-4902) or 10 nM HY (Sigma, Cat. H-0135).

\section{Experiment 2}

For studies examining the effects of FFA, cells were cultured in basic media containing $0 \cdot 15 \%$ FFA-free BSA (Sigma, Cat. A-7030) and 10\% HS. After a 48-h incubation, cultures were rinsed in serum-free media and incubated for $1 \mathrm{~h}$ and the media were then replaced with serum-free media containing oleic acidalbumin or linoleic acid-albumin complexes (2 mol fatty acid:1 mol BSA; Sigma, Cat. O-3008 and L-9530 respectively) at 100 or $400 \mu \mathrm{M}$ fatty acid. Controls consisted of serum-free media containing $50(0 \cdot 3 \%)$ or $200 \mu \mathrm{M}(1 \cdot 2 \%)$ FFA-free BSA.

\section{Experiment 3}

For studies examining the direct effects of insulin and IGF-I, culture conditions previously reported by Melmed and colleagues were used (Yamashita \& Melmed 1986a, Morita et al. 1987). Specifically, cells were cultured in $\alpha$-MEM (Invitrogen) containing 2.5\% fetal bovine serum (FBS) (Sigma, Cat. F-4135), 0.1\% BSA (Sigma, Cat. A-7906), transferrin (125 nM, Sigma, Cat. T-2252), T3 $(0.6 \mathrm{nM}$, Sigma, Cat. T-5516), HY $(275 \mathrm{nM})$ and penicillin-streptomycin. After a 24-h incubation, cultures were preincubated in serum-free media for $1 \mathrm{~h}$ and the media was then replaced with serum-free media containing 0 (control group), $0 \cdot 5,1$, 5,10 or $50 \mathrm{nM}$ insulin or IGF-I (Sigma, Cat. I-8530 and I-3769 respectively).

\section{Comparison of insulin receptor (INSR) and IGF-I receptor (IGF-IR)}

For all experiments described above, the treatments were applied for $24 \mathrm{~h}$ (3-4 wells/treatment group) and the media were recovered and stored at $-80^{\circ} \mathrm{C}$ for analysis of GH concentrations on selected samples, by a human GH ELISA (DSL, Webster, TX, USA, Cat. DSL-10-1900). Also, total RNA was extracted for subsequent determination of 
mRNA levels by quantitative real-time (qrt) reversetranscripted (RT)-PCR, as described below.

mRNA in baboon tissues INSR and share significant structural homology, are activated by their respective ligands at high doses and can signal through common intracellular pathways (Nakae et al. 2001). Therefore, studies were conducted to determine if the baboon pituitary expressed the INSR at levels comparable to tissues commonly thought of as 'insulin-sensitive' (i.e. liver, fat, and skeletal muscle) and how the level of pituitary INSR expression compared with the level of IGF-IR expression. To this end, pituitary, hypothalamus, liver, visceral fat, and skeletal muscle (pectoralis major) were obtained after euthanasia from randomly cyclic female baboons. Tissues (50-100 mg) were extracted for total RNA and qrtRT-PCR was performed to determine absolute copy numbers of INSR and IGF-IR mRNA levels as described below.

\section{RNA isolation and reverse transcription}

Total RNA from primary pituitary cell cultures and whole tissues was extracted using the absolutely RNA RT-PCR Miniprep kit (Stratagene, La Jolla, CA, USA) with DNse treatment according to the manufacturer's instructions. The amount of RNA recovered was determined by the Ribogreen RNA quantification kit (Molecular Probes, Eugene, OR, USA). Total RNA $(0 \cdot 25 \mu \mathrm{g}$ from primary pituitary cultures and $1 \mu \mathrm{g}$ for whole tissue extracts) was $\mathrm{RT}$ in a $20 \mu \mathrm{l}$ volume using random hexamer primers and reagents supplied in the cDNA First Strand Synthesis kit (MRI Fermentas, Hanover, MD, USA). The cDNA obtained was treated with ribonuclease $\mathrm{H}$ (1 U, MRI Fermentas) and duplicate aliquots $(1 \mu \mathrm{l})$ of the resulting cDNA was amplified by qrtRT-PCR, where samples were run against synthetic standards to estimate mRNA copy number (see below).

\section{Partial sequencing of baboon GH, GHRH-R, GHS-R, INSR, IGF-IR, Pit-1 and cyclophilin A}

cDNA and real-time PCR primer selection. In order to obtain nucleotide sequences of the coding regions of the baboon transcripts, published cDNA sequences were aligned from a variety of mammalian species, including human, chimpanzee, monkey, rat and mouse; then primers were selected corresponding to areas of $100 \%$ homology. Primers were selected using the Primer 3 Software (S Rozen and H Skaletsky, 2000, Whitehead Institute for Biomedical Research, Cambridge, MA, USA) with selection parameters set to (1) pick primers that differ by no more than $0 \cdot 2^{\circ} \mathrm{C}$ in annealing temperature, (2) exclude primers that may form primer dimers, and (3) amplify a product of 400-800 bp. Primers were then used in a standard PCR with the 2x Master Mix PCR reagent (MRI Fermentas) and cDNA from a normal baboon pituitary, as template. The thermocycling profile consisted of one cycle of $95^{\circ} \mathrm{C}$ for $10 \mathrm{~min}$, followed by 35 cycles of 95,61 and $72{ }^{\circ} \mathrm{C}$ for $1 \mathrm{~min}$ each, and a final cycle of $72^{\circ} \mathrm{C}$ for $10 \mathrm{~min}$. Products were run on agarose gels and stained with ethidium bromide to confirm that only one band, of the expected size, was amplified and no primer dimers formed. These PCR products were then column-purified (QUIAquick PCR purification kit, Qiagen, Cat. 28104) and subjected to PCR automated sequencing. To confirm sequence accuracy, PCR products from two separate baboon pituitaries were sequenced using forward and reverse priming. These sequences were found to be homologous to the respective transcripts of other species. Sequences were submitted to Genbank (accession numbers are shown in Table 1) and used as templates to design nested primers appropriate for real-time PCR using Primer 3 Software (National Center for Biotechnology Information, USA), choosing primers that generated products between 100 and $200 \mathrm{bp}$. These primers were used in a standard PCR and

Table 1 Primers specific for baboon (Papio anubis) cDNA transcripts, used for the real-time PCR

Genbank accession no. Primer sequence

$\begin{array}{ll}\begin{array}{ll}\text { Gene } \\ \text { GH }\end{array} & \text { DQ340390 } \\ \text { GHRH-R } & \text { DQ340391 } \\ \text { GHS-R } & \text { DQ340392 } \\ \text { INS-R } & \text { DQ340393 } \\ \text { IGF-IR } & \text { DQ340394 } \\ \text { PIT-1 } & \text { DQ453815 } \\ \text { Cyclophilin A } & \text { DQ315473 }\end{array}$

Nucleotide position

Product size

Sense: GACCTAGAGGAAGGCATCCAAA Antisense:AGCAGCCCGTAGTTCTTGAGTAG Sense: TCACCATCCTGGTTGCTCTC Antisense: GCAGCATCCTTCAGGAACAC Sense: GTGTGGGTGTCCAGCATCTT Antisense: CACGGTTTGCTTGTGGTTCT Sense: ACGCTCTGGTGTCACTTTCCT Antisense: AGCTGCCTTAGGTTCTGGTTG Sense: GAGGAAGTGACGGGGACTAAA Antisense: GTGGTGGTGGAGGTGAAATG Sense: TGGAGTGATGGCAGGTAGTTT Antisense: TTACTTTTCCGCCTGAGTTCC Sense: CAAGACGGAGTGGTTGGATG Antisense: TGGTGGTCTTCTTGCTGGTC

$\begin{array}{ll}\text { Sn 21 As 163 } & 143 \\ \text { Sn } 74 \text { As } 185 & 112 \\ \text { Sn 389 As 535 } & 147 \\ \text { Sn 287 As 398 } & 112 \\ \text { Sn 139 As 251 } & 113 \\ \text { Sn 54 As 200 } & 147 \\ \text { Sn 351 As 472 } & 122\end{array}$

Sn 351 As 472 
products were run on agarose gels and stained with ethidium bromide to confirm that only one band was amplified and no primer dimers formed. PCR products were then column-purified (Qiagen) and again sequenced to confirm target specificity.

\section{Confirmation of primer efficiency, construction of standard curves, and qrtRT-PCR}

The initial screening of primer efficiency in a real-time PCR was performed by amplifying two-fold dilutions of RT products generated from total RNA extracted from whole baboon pituitaries, where optimal efficiency was demonstrated by a difference of one cycle threshold between dilutions. At the end of the amplification, the final products were subjected to graded temperaturedependent dissociation to verify that only one product was amplified. For real-time PCR, IQ SYBR Green Supermix (BioRad) was used, where thermocycling and fluorescence detection was performed using a Stratagene Mx3000p real-time PCR machine. If the preliminary primer efficiency tests were confirmed, the concentration of purified PCR products (generated by standard PCR and purified for sequencing as described above) was determined using Molecular Probe's Picogreen DNA quantification kit and the PCR products were serial diluted to obtain standards containing $10^{1}, 10^{2}$, $10^{3}, 10^{4}, 10^{5}$, and $10^{6}$ copies of synthetic template per $1 \mu \mathrm{l}$. Standards were then amplified by real-time and standard curves generated by the Stratagene Mx3000p Software. The final volume $(\mu \mathrm{l})$ of the PCR was 25:1 of RT sample, $12.5 \mu \mathrm{l}$ of the IQ SYBR Green Supermix, $0.375 \mu \mathrm{l}$ of each primer $(10 \mu \mathrm{M}$ stock solution; $150 \mathrm{nM}$ final), $0.375 \mu \mathrm{l}$ of the reference dye (BioRad) and $10 \cdot 375 \mu \mathrm{l}$ of distilled $\mathrm{H}_{2} \mathrm{O}$. Thermal cycling profile consisted of a pre-incubation step at $95^{\circ} \mathrm{C}$ for $10 \mathrm{~min}$, followed by 40 cycles of denaturation $\left(95^{\circ} \mathrm{C}, 30 \mathrm{~s}\right)$, annealing $\left(61{ }^{\circ} \mathrm{C}, 1 \mathrm{~min}\right)$ and extension $\left(72^{\circ} \mathrm{C}, 30 \mathrm{~s}\right)$. The efficiency of amplification for all curves was between 97 and $103 \%$, which means that all templates in each cycle were copied. To estimate the starting copy number of cDNA, RT samples were PCR amplified and the signal compared with that of a standard curve run on the same plate. In addition, total RNA samples that were not RT and a no-DNA control were routinely run in each plate to control for genomic DNA contamination and to monitor potential exogenous contamination respectively. For in vitro studies examining the direct impact of metabolic factors on somatotrope expression, mRNA copy number of the transcript of interest was adjusted by the mRNA copy number of cyclophilin A (a peptidyl isomerase) to control for variations in the amount of RNA used in the $\mathrm{RT}$ reaction and the efficiency of the RT reaction. It should be noted that cyclophilin A mRNA levels did not vary between in vitro treatment groups. However, the analysis of cyclophilin A revealed variations between tissue type; therefore, mRNA for INSR and IGF-IR in the various tissues studied are presented as absolute mRNA copy number $/ 0 \cdot 05 \mu \mathrm{g}$ total RNA.

\section{Statistical analysis}

Samples from all doses for each treatment within experiments were processed at the same time. Each treatment was repeated a minimum of three times on different pituitary cell preparations. The basal mRNA values and $\mathrm{GH}$ released into the media varied between each pituitary cell preparation, likely due to age, body condition and reproductive status, which were out of our control. However, the relative response to treatment was consistent across experiments. Therefore, within experiments, values were normalized to vehicletreated controls (set at 100\%) and the results are reported as means \pm s.E.M. of all experiments. Dose effects of DEX, IGF-I and insulin were assessed by oneway ANOVA and the effects of BSA concentration and FFA dose were assessed by two-way ANOVA, followed by Newman's Keuls test for multiple comparisons and $P<0.05$ was considered significant. All statistical analyses were performed using the GB-STAT Software package (Dynamic Microsystems, Inc., Silver Spring, MD, USA).

\section{Results and discussion}

\section{Direct effects of glucocorticoids}

As shown in Fig. 1A and C, DEX, a synthetic glucocorticoid, significantly stimulated $\mathrm{GH}$ and GHRH-R mRNA levels at $5 \mathrm{nM}$, while a significant upregulation of GHS-R mRNA levels required higher doses of DEX (10 nM, Fig. 1D). Not only was the GHS-R two-fold less sensitive to the stimulatory actions of DEX, but also the maximal effect of DEX on GHS-R mRNA levels ( $81 \%$ above vehicle-treated controls) was approximately half of that observed for GH and GHRH-R (156 and $141 \%$ respectively). Exposure of baboon pituitary cell cultures to $10 \mathrm{nM}$ HY (Fig. 1, shaded bars), the major circulating glucocorticoid in primates, also stimulated GH, GHRH-R and GHS-R mRNA levels, where the response was comparable to that observed following exposure to $10 \mathrm{nM}$ DEX. Glucocorticoidstimulated GH mRNA levels were reflected by an increase in GH released into the media (Fig. 1B), suggesting that the increase in GH mRNA is translated into an increase in protein production. These observations are consistent with previous reports showing that glucocorticoids can directly stimulate GH mRNA levels in rat GH-producing pituitary cell lines (Evans et al. 1982, Spindler et al. 1982), as well as stimulate GH, GHRH-R and GHS-R mRNA levels in primary rat 
(A)

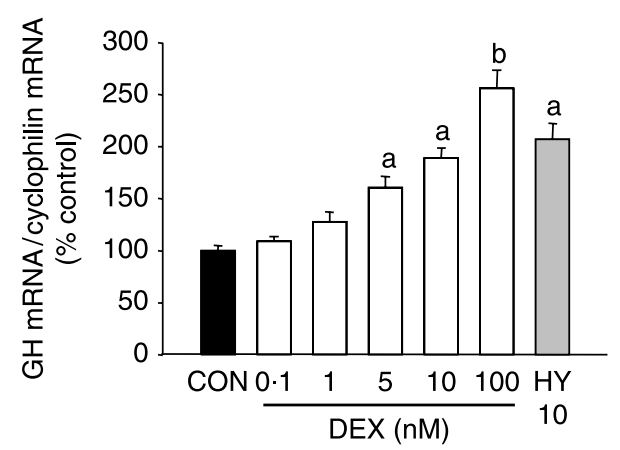

(B)

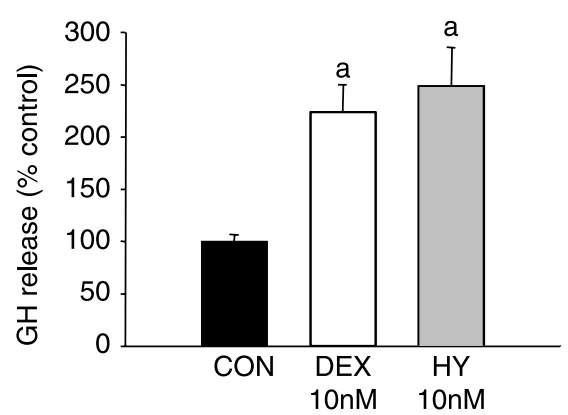

(C)

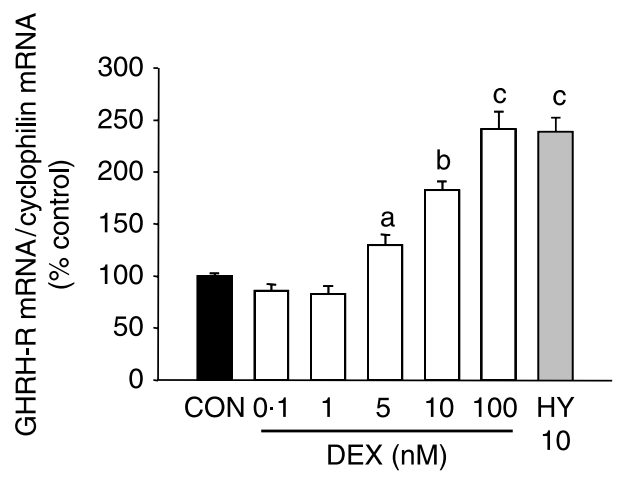

(D)

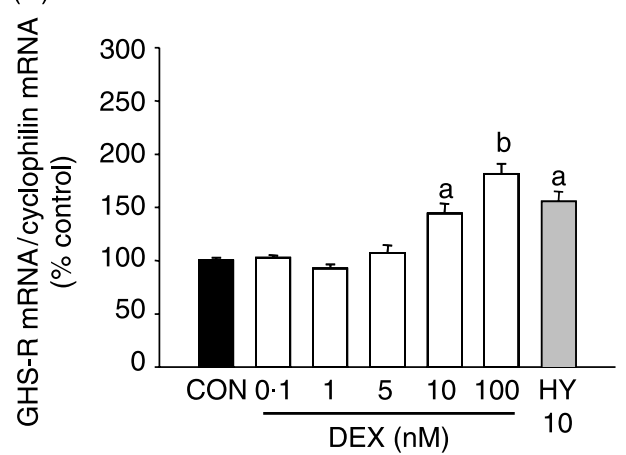

Figure 1 Effect of dexamethasone (DEX) and hydrocortisone (HY) treatment (24 h) on GH mRNA (A), GH release (B), GHRH-R mRNA (C) and GHS-R mRNA (D) in primary baboon pituitary cell cultures. mRNA copy numbers were determined by quantitative real-time RT-PCR and adjusted by cyclophilin A mRNA copy number, as a housekeeping gene. The amount of $\mathrm{GH}$ released into the media was determined by ELISA. All values are expressed as percent of vehicle-treated controls (CON; set at $100 \%$ ) and represent the mean \pm S.E.M. of four independent experiments (3-4 wells/treatment/experiment). Dose responses were assessed by one-way ANOVA and values that differ $(P<0 \cdot 05)$ are designated by different letters $(a, b$, and $c)$.

pituitary cell cultures (Martinoli et al. 1991, Tamaki et al. 1996, Miller \& Mayo 1997, Tamura et al. 2000). These results are also consistent with early reports demonstrating that glucocorticoids enhance GH mRNA levels and GH release in cell cultures prepared from human somatotropinomas (Oosterom et al. 1984, Nakagawa et al. 1985, Isaacs et al. 1987).

Although it is clear that glucocorticoids directly enhance GH synthesis across diverse species, the mechanism by which they mediate this effect is not clear-cut. In reporter assay systems, glucocorticoids have been shown to have stimulatory, inhibitory, or no effect on basal transcriptional activity of the GH gene, depending on the species studied, time of exposure and length of promoter used. Glucocorticoids modestly stimulate the activity of the hGH gene promoter, where this effect has been isolated to an atypical glucocorticoid response element (GRE) located in the first intron (Slater et al. 1985, Brent et al. 1988). In contrast, the rGH gene promoter lacks consensus GREs and is unresponsive to glucocorticoid stimulation, and in some reports, promoter activity is actually inhibited by glucocorticoid treatment (Brent et al. 1988, Strobl et al. 1989, Iwasaki et al. 2003). However, glucocorticoids have also been shown to enhance rat GH mRNA levels by stabilizing the transcript (Paek \& Axel 1987). In addition, glucocorticoids work synergistically with thyroid hormone to enhance the expression of both the rat and human GH transcripts (Evans et al. 1982, Spindler et al. 1982, Martinoli et al. 1991, Iwasaki et al. 2003).

Although glucocorticoids clearly stimulate GHRH-R and GHS-R mRNA levels in the rat (Tamaki et al. 1996, Miller \& Mayo 1997, Tamura et al. 2000), to our knowledge, this is the first report demonstrating that glucocorticoids directly enhance endogenous expression of the GH-stimulatory receptors GHRH-R and GHS-R in a primate model. A role for glucocorticoids in promoting human GHRH-R gene expression was previously implicated in studies performed by Petersenn et al. (1998), who examined hormonal regulation of hGHRH-R promoter-luciferase reporter construct in the rat pituitary cell line, GH4. They observed that HY significantly stimulated reporter activity; however, the hGHRH-R promoter did not 
contain a consensus GRE. In a later study, Petersenn et al. (2001) reported HY suppressed hGHS-R genepromoter activity and this inhibitory effect was localized to the proximal promoter where a putative GRE site was located upstream at position - 1464 . These later results are in sharp contrast with the current observation that glucocorticoids enhance endogenous GHS-R mRNA levels in a primate model. Possibilities that may explain these divergent results include: (1) response elements regulating the stimulatory effect of glucocorticoids may be located outside the promoter region studied, (2) glucocorticoids may regulate GHS-R mRNA indirectly by upregulating stimulatory factors or downregulating inhibitory factors, where this effect is dependent on the cell system studied, and/or (3) the effects of glucocorticoids on GHS-R mRNA levels may differ between species. The last possibility seems less likely given the fact that glucocorticoids have also been shown to directly enhance GHS-R mRNA levels in primary rat pituitary cell cultures (Tamura et al. 2000).

Despite the clear stimulatory effects of glucocorticoids on somatotrope function in vitro, the effects in vivo vary. Individuals with primary adrenal insufficiency do have lower levels of circulating $\mathrm{GH}$, where replacing glucocorticoids to mimic physiologic concentrations and patterns enhances GH release (Barkan et al. 2000). Positive effects of glucocorticoids have also been noted after acute treatment in normal subjects (Casanueva et al. 1990). However, more prolonged, high-dose glucocorticoid therapy or elevations in endogenous glucocorticoids due to primary or secondary adrenal hyperactivity is associated with suppressed GH output, which has been attributed to a reciprocal shift in hypothalamic GHRH and SST input (as reviewed by Dieguez et al. 1996).

\section{Direct effects of FFA}

Non-esterified FFA circulate at high concentrations bound to albumin, where oleic and linoleic acid comprise up to 40 and $27 \%$ respectively of the total FFA found in the circulation (Richieri \& Kleinfeld 1995). Therefore, in order to test the direct effects of FFA on somatotrope function, primary baboon pituitary cell cultures were treated with oleic-albumin or linoleicalbumin complexes at molar ratio of $2: 1$, where each BSA molecule has been reported to bind up to six molecules of FFA with high affinity (Sector et al. 1969). Two-way ANOVA revealed that BSA concentration (50 vs $200 \mu \mathrm{M})$ had an overall stimulatory effect on GH mRNA levels $(P<0 \cdot 023)$, while increased BSA concentrations tended to suppress GHRH-R and GHS-R mRNA levels $(P<0 \cdot 091$ and $P<0 \cdot 096$ respectively). Assessment of the effects of FFA demonstrated an overall inhibitory effect of FFA on GH, GHRH-R and GHS-R mRNA levels
$(P<0 \cdot 001)$. Specifically, a maximum inhibitory effect of FFA on GH mRNA levels was observed at $100 \mu \mathrm{M}$ oleic acid $(81 \% \pm 1$ of control) and $400 \mu \mathrm{M}$ linoleic acid ( $70 \% \pm 5$ of control; Fig. 2A). Oleic and linoleic acid (at $400 \mu \mathrm{M}$ ) also suppressed basal GH release to $52 \pm 4$ and $64 \% \pm 6$ of control values (Fig. 2B). GHRH-R mRNA was highly sensitive to the inhibitory actions of FFA (Fig. 2C), where maximum suppression of GHRH-R mRNA occurred at $400 \mu \mathrm{M}$ oleic $(24 \% \pm 0 \cdot 5$ of control $)$ and linoleic acid ( $25 \% \pm 0 \cdot 8$ of control). However, GHS$\mathrm{R}$ mRNA levels were less sensitive to the inhibitory effects of FFA, where only $400 \mu \mathrm{M}$ of linoleic acid caused a significant suppression (Fig. 2D).

The inhibitory effect of FFA on GH release, observed in this study, is consistent with a previous report in which oleic acid suppressed both basal and GHRH-stimulated GH release in primary pituitary cultures from rats following a $20 \mathrm{~h}$ exposure (Kennedy et al. 1994). An inhibitory effect of oleic acid on stimulated (GHRH, forskolin or dbcAMP) GH release has also been observed after acute (5-60 min) exposure in primary rat pituitary cell cultures and in a rat GH-producing pituitary cell line, GH3 (Casanueva et al. 1987, Pérez et al. 1997, 1998). Results of studies conducted using GH3 cells suggest FFA blocks GH release by suppressing adenylate cyclase and PKA activity and reducing $\mathrm{Ca}^{2+}$ influx (Pérez et al. 1997, 1998). The inhibitory effect of FFA on GH release is also observed in vivo, where acute elevation of circulating FFA, using lipid heparin infusion, dramatically suppresses GHRH-stimulated $\mathrm{GH}$ release in normal rat and human subjects (Casanueva et al. 1987, Alvarez et al. 1991). Given that the inhibitory actions of FFA on GH release can still be observed in rats treated with anti-SST antiserum or in rats with hypothalamic ablation (Alvarez et al. 1991), it is believed that the primary pathway by which FFA inhibits GH output is by a direct effect on somatotrope function.

An acute elevation in circulating FFA can not only suppress GH release; conversely an acute reduction circulating FFA by acipimox (an anti-lipolytic agent), results in enhanced basal and GHRH-stimulated GH release in lean and obese subjects (Nam et al. 1996, Kok et al. 2004). However, GH release in obese subjects treated with acipimox is less than that observed in lean controls, suggesting FFA-mediated suppression of GH release may contribute to obesity-associated $\mathrm{GH}$ suppression, but it is not the only component. This hypothesis is consistent with the current novel observations demonstrating that 24-h exposure to FFA not only suppressed GH release, but also reduced GH, GHRH-R and GHS-R mRNA levels. Therefore, FFA-mediated suppression of GH and its stimulatory receptors may, in part, explain the blunted $\mathrm{GH}$ response of obese subjects to GHRH and synthetic 


\section{CONTROL (C) $\square$ OLEIC ACID (O) $\square$ LINOLEIC ACID (L)}

(A)

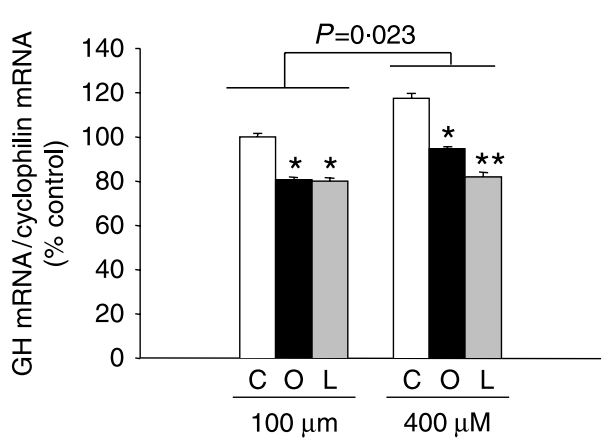

(B)

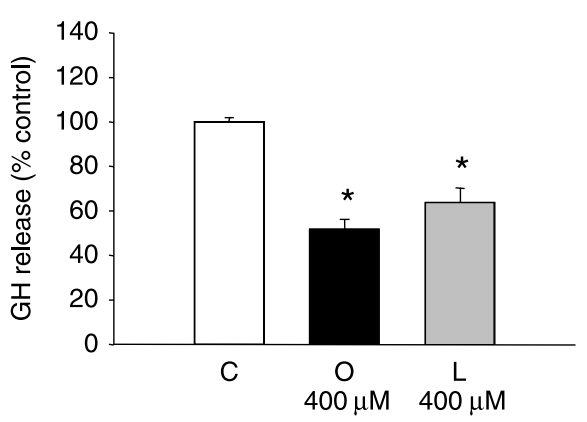

(C)

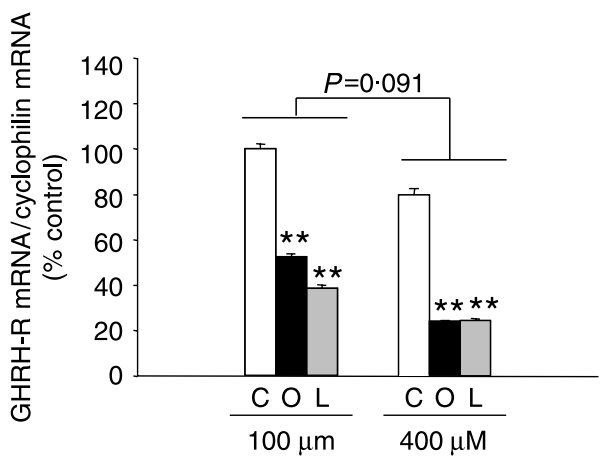

(D)

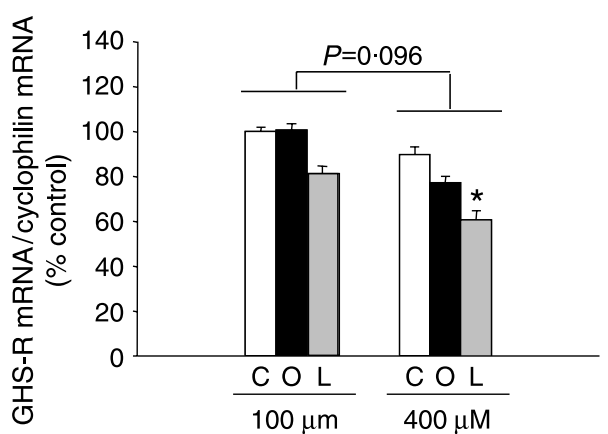

Figure 2 Effects of 100 and $400 \mu \mathrm{M}$ oleic $(\mathrm{O})$ and linoleic $(\mathrm{L})$ acid treatment $(24 \mathrm{~h})$ on GH mRNA (A), GH release (B), GHRH-R mRNA (C) and GHS-R mRNA (D) in primary baboon pituitary cell cultures. mRNA copy numbers were determined by quantitative real-time RT-PCR and adjusted by cyclophilin A mRNA copy number, as a housekeeping gene. The amount of GH released into the media was determined by ELISA. Free fatty acids (FFA) were supplied to the cultures complexed to BSA at a 2:1 molar concentration. Therefore, cultures containing $50 \mu \mathrm{M}$ BSA or $200 \mu \mathrm{M}$ BSA (FFA-free) were used as controls (C). Values are presented as percent of $50 \mu \mathrm{M}$ BSA-treated controls (set at 100\%) and represent the mean \pm S.E.M. of four independent experiments (3-4 wells/treatment per experiment). Two-way ANOVA was used to separate out the effects of BSA and FFA on mRNA levels. The overall effect of BSA on GH, GHRH-R and GHS-R mRNA levels is indicated by the $P$ values shown in panels (A), (C) and (D). Effect of $400 \mu \mathrm{M} \mathrm{FFA}$ on GH release was assessed by one-way ANOVA. Asterisks indicate values that differ from their respective BSA controls; ${ }^{\star} P<0 \cdot 05,{ }^{\star}{ }^{\star} P<0 \cdot 01$.

GHS-R agonists and the reduced responsiveness of primary rat pituitary cultures to GHRH after prolonged exposure to FFA (Kennedy et al. 1994, Scacchi et al. 1999, Cordido et al. 2003, Qu et al. 2004, Haijma et al. 2005). A direct role of elevated FFA in modulating more long-term changes in somatotrope function is supported by the observation that the $\mathrm{GH}$ response to GHRH in patients treated with acipimox for 30 days can be normalized (Nam et al. 1996). However, it should be noted that prolonged lowering of circulating FFA levels by acipimox enhances insulin sensitivity and lowers circulating insulin levels (de Jongh et al. 2004, Bajai et al. 2005), where hyperinsulinemia may also directly contribute to suppressed somatotrope function in the obese state, as discussed below.

\section{Direct effects of IGF-I and insulin}

IGF-I has long been recognized as a direct inhibitor of somatotrope function and has been shown to suppress both GH release and synthesis in rat pituitary cell lines, primary rat pituitary cell cultures and human somatotropinomas (Yamashita \& Melmed 1986c, 1987, Morita et al. 1987, Melmed et al. 1996). IGF-I has also been shown to decrease GHRH-R (Sugihara et al. 1999) and GHS-R (Kamegai et al. 2005) mRNA levels in primary rat pituitary cell cultures. The current findings are consistent with previous reports, in that 24-h treatment with IGF-I significantly suppressed GH release and GH, GHRH-R and GHS-R mRNA levels in primary baboon pituitary cell cultures (Figs $3 \mathrm{~A}$ and $\mathrm{B}$ and $4 \mathrm{~A}$ and $\mathrm{B}$ ). The effects of IGF-I on GH, GHRH-R and GHS-R mRNA 
levels were dose-dependent, where a significant suppression was observed at the lowest dose tested $(0.5 \mathrm{nM})$ with a maximal suppression occurring between 5 and $10 \mathrm{nM}$, achieving $<50 \%$ of controls. This observation is of particular note in that circulating levels of 'free' IGF-I in humans are reported to be $0 \cdot 2-0 \cdot 4 \mathrm{nM}$ under normal conditions; where free IGF-I represents that which is unbound or associated with IGF-binding proteins (IGFBP) with low affinity and is, therefore, available to activate the IGF-IR (Frystyk 2004). The importance of IGFBP in specifically mediating actions of IGF-I on GH expression has been observed in vitro (Voss et al. 2001). These results, taken together with the current observations, suggest that even under normal conditions, regulation of GH, GHRH-R and GHS-R expression is under direct tonic inhibition by low circulating levels of free IGF-I. This notion is consistent with the observation that circulating $\mathrm{GH}$ and pituitary
GHRH-R and GHS-R mRNA levels are elevated in liverspecific IGF-I knockout mice, where circulating IGF-I levels are less than $10 \%$ of normal controls, while hypothalamic GHRH or SST expression do not differ from controls (Sjogren et al. 1999, Yakar et al. 1999, Wallenius et al. 2002). It has also been hypothesized that suppression of free IGF-I levels observed following fasting and increases in free IGF-I reported in obesity may play a role in the reciprocal changes in GH output in these extreme metabolic conditions (for review, see Frystyk 2004). Although this hypothesis remains to be tested in an in vivo primate model, an exclusive role for IGF-I in regulating somatotrope receptor expression in acute fasting is lessened by our previous observation that a fasting-induced rise in GHRH-R and GHS-R still occurs in the GH-deficient, spontaneous dwarf rat, despite the already low (10\% of normal) levels of IGF-I (Park et al. 2004).
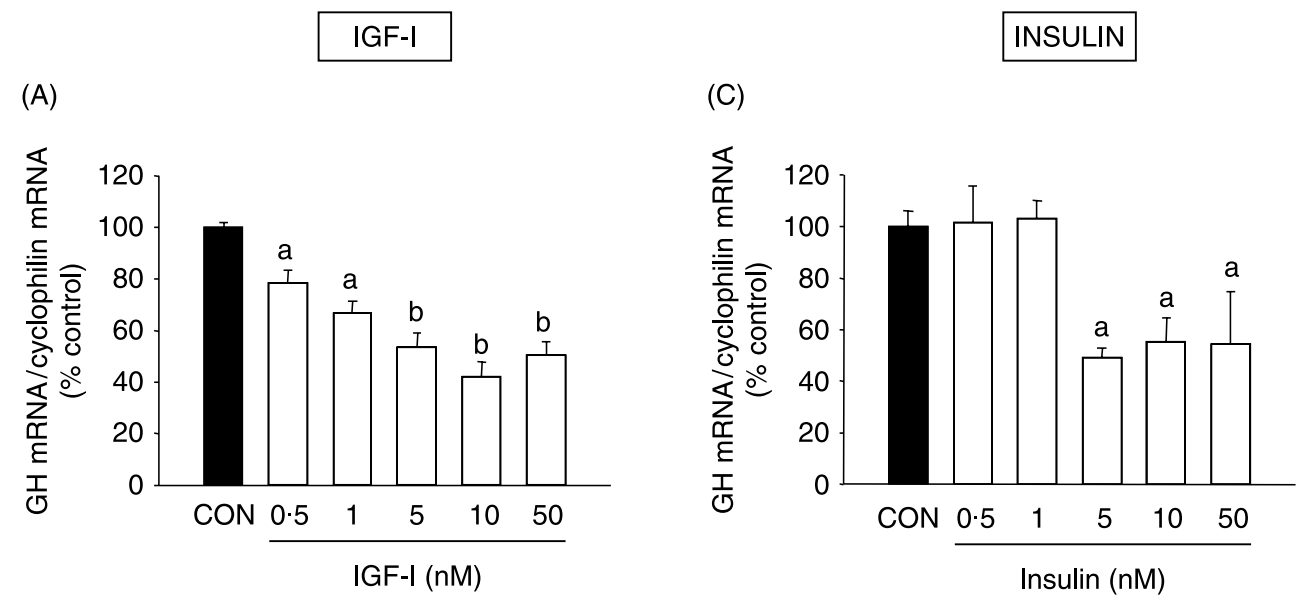

(B)

(D)
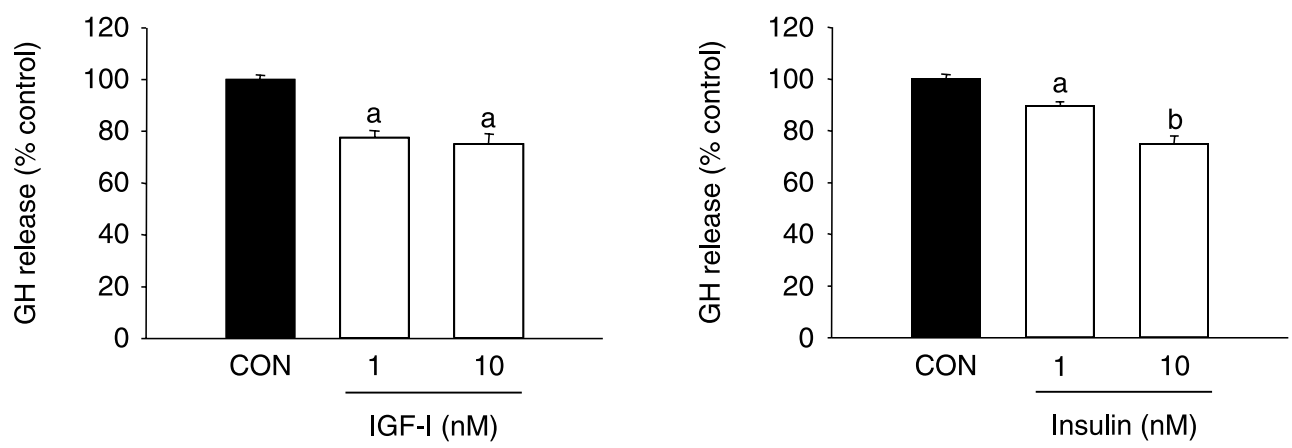

Figure 3 Effect of IGF-I and insulin treatment $(24 \mathrm{~h})$ on GH mRNA (A) and (C) and GH release (B) and (D) in primary baboon pituitary cell cultures. GH mRNA copy number was determined by quantitative real-time RT-PCR and adjusted by cyclophilin A mRNA copy number, as a housekeeping gene. The amount of GH released into the media was determined by ELISA. All values are expressed as percent of vehicle-treated controls (CON; set at 100\%) and represent the mean \pm S.E.M. of four independent experiments (3-4 wells/treatment per experiment). Dose responses were assessed by one-way ANOVA and values that differ $(P<0 \cdot 05)$ are designated by different letters $(\mathrm{a}$ and $\mathrm{b})$. 
IGF-I INSULIN

(A)

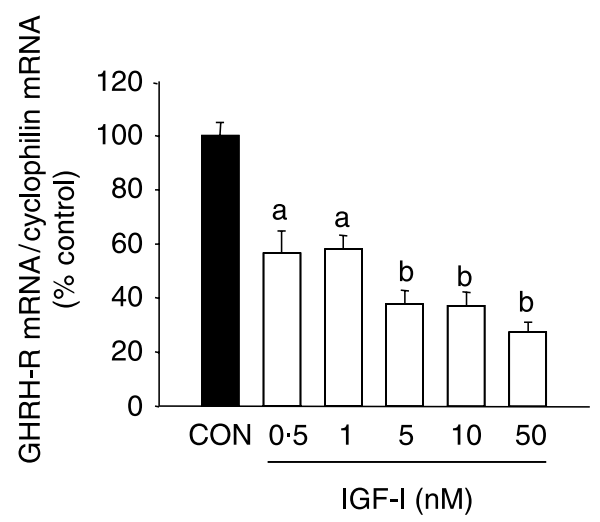

(B)

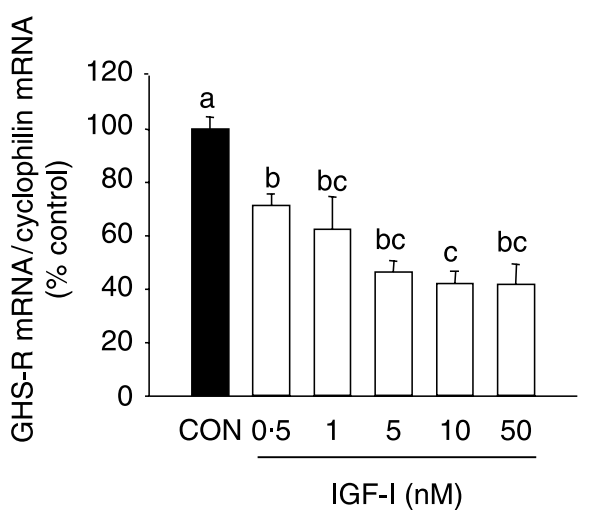

(C)

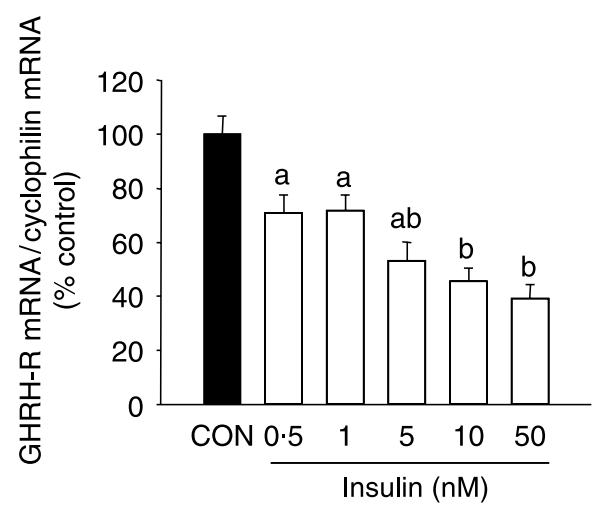

(D)

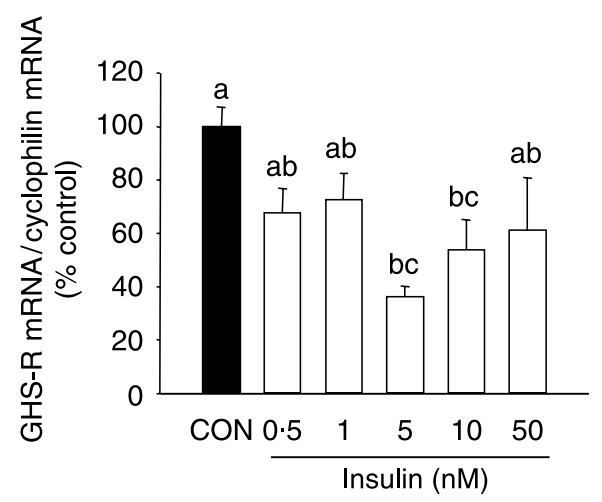

Figure 4 Effect of IGF-I and insulin treatment (24 h) on GHRH-R mRNA (A) and (C) and GHS-R (B) and (D) in primary baboon pituitary cell cultures. GHRH-R and GHS-R mRNA copy number was determined by quantitative real-time RT-PCR and adjusted by cyclophilin A mRNA copy number as a housekeeping gene. All values are expressed as percent of vehicle-treated controls (set at 100) and represent the mean \pm S.E.M. of four independent experiments (3-4 wells/treatment per experiment). Dose responses were assessed by one-way ANOVA and values that do not share a common letter $(a, b$, and $c)$ differ $(P<0.05)$.

Although IGF-I has long been recognized as a direct inhibitor of somatotrope function, limited information is available as to the mechanism by which IGF-I mediates these inhibitory effects. Only two reports have been published investigating this pathway with respect to IGF-I-mediated suppression of GH gene expression. Voss et al. (2000) demonstrated that IGF-I decreased endogenous GH mRNA in $\mathrm{MtT} / \mathrm{S}$ cells, a GH-producing rat pituitary cell line, and this inhibitory effect could not be blocked by inhibitors of phosphatidyl inositol 3 kinase (PI3K) (wortmannin and LY294002) or MAPK (PD098059). In contrast, Niiori-Onishi et al. (1999), also using MtT/S cells, reported that IGF-I suppressed luciferase activity driven by a hGH gene promoter, where this action could be blocked by treatment with wortmannin. These divergent results demonstrate that regulation of the endogenous gene vs reporter gene activity may be very different even in the same cell type. Also, species-specific promoters may be differentially regulated. Finally, these diverse observations raise the possibility that endogenous gene regulation in primary culture may differ from those of continuous cell lines.

Like IGF-I, insulin directly inhibits GH release and GH, GHRH-R and GHS-R mRNA levels in primary baboon pituitary cell cultures; however, the dose-dependent pattern of mRNA suppression differed from IGF-I (Figs $3 \mathrm{C}$ and $\mathrm{D}$ and $4 \mathrm{C}$ and D). Low doses of insulin $(0.5$ and $1 \mathrm{nM})$, representing values that could be achieved in vivo in the fasted state, did not alter GH mRNA levels but did result in a small but significant suppression of GH release (11\%) and GHRH-R and 
GHS-R mRNA levels $(30 \%)$ compared with vehicletreated controls. Higher doses of insulin ( 5 and $10 \mathrm{nM})$, representative of circulating levels achieved in patients with systemic insulin resistance and obesity, result in a $25 \%$ suppression of $\mathrm{GH}$ release and a $\geq 50 \%$ suppression GH, GHRH-R and GHS-R mRNA levels. These data clearly demonstrate that insulin, at physiologically relevant concentrations, can directly inhibit pituitary expression of genes important in both GH synthesis and release. The fact that insulin can suppress mRNA levels at doses well below that predicted to bind and activate the IGF-IR (Rosenfeld et al. 1984, Burguera et al. 1991) suggests insulin is likely working through its own receptor, INSR, to mediate these effects. This conclusion is consistent with the previous reports demonstrating that insulin can suppress GH synthesis and release in rat pituitary cell lines and in primary rat pituitary cell cultures, where the inhibitory effects of insulin on GH gene transcription could be blocked by pretreatment with antisera raised against the INSR (Yamashita \& Melmed 1986b). Although the pituitary is not typically considered as an 'insulin-sensitive' tissue, a dominant role for insulin in regulating pituitary function is further supported by the observation that INSR mRNA levels in the baboon pituitary are comparable or greater than INSR expression in the fat, skeletal muscle and liver (Fig. 5). The ability of qrtRT-PCR to detect differences in receptor expression is supported by the observation that liver IGF-IR mRNA levels are substantially less than the other tissues tested. This observation is consistent with previous reports showing that normal hepatocytes, although they represent a major tissue source for the circulating ligand, do not express the IGF-IR (Caro et al. 1988, Yakar et al. 1999). A key role for insulin in directly regulating GH output in vivo is further supported by our recent findings that (1) pituitaries of obese/ hyperinsulinemic mouse models have reduced

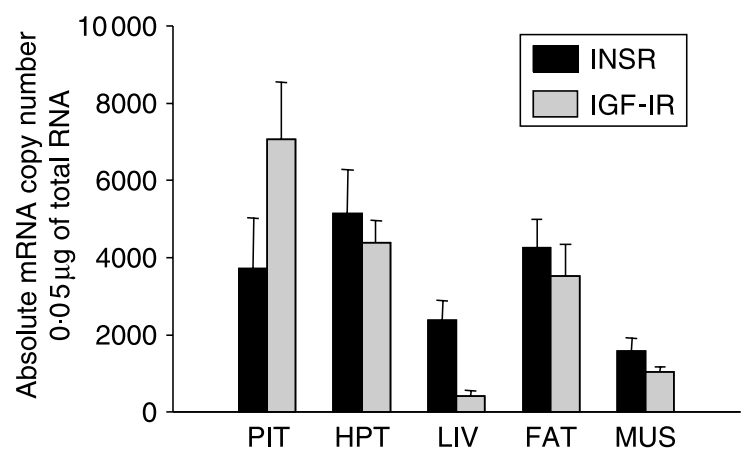

Figure 5 Absolute insulin receptor (INSR) mRNA and IGF-I receptor (IGF-IR) mRNA copy number in the pituitary (PIT), hypothalamus (HPT), liver (LIV), fat (FAT) and skeletal muscle (MUS, pectoralis major) taken from randomly cyclic adult female baboons ( $n=3-7$ samples/tissue tested), as determined by quantitative real-time RT-PCR. expression of pituitary GH, GHRH-R and GHS-R, independent of changes in hypothalamic GHRH and SST expression, (2) mouse pituitaries express the INSR at levels comparable to insulin-sensitive tissues, (3) pituitaries of obese mice remain responsive to the acute actions of insulin, despite systemic insulin resistance, and (4) changes in pituitary expression observed in obese/hyperinsuliniemic mice can be replicated by insulin administration in vitro (Luque \& Kineman 2006).

\section{The direct effects of glucocorticoids, FFA, insulin and IGF-I on somatotrope function are not associated with changes in Pit-1 expression}

In the current report, the direct effects of glucocorticoids, FFA, insulin and IGF-I on somatotrope function were examined after a 24-h incubation. This time of incubation was chosen to more accurately reflect chronic changes in the metabolic milieu due to underor over-nutrition. Given the extended duration of incubation, it is uncertain if the effects observed on GH, GHRH-R and GHS-R mRNA levels are due to a direct effect of these factors on GH, GHRH-R or GHS-R gene expression or are mediated via secondary changes in the expression of other critical regulatory proteins. Of particular interest is pituitary-specific transcription factor-1 (Pit-1, aka GHF-1), which is required for normal expression of the somatotrope population during pituitary development and in vivo expression of $\mathrm{GH}$ and GHRH-R (for review, see Andersen \& Rosenfeld 2001). The effects of Pit-1 on GH and GHRH-R gene expression are direct, in that Pit-1 response elements are located on the GH and GHRH-R gene promoters and Pit-1 can activate expression of the GH and GHRH-R promoter-driven reporter genes in heterologous cell systems (Mayo et al. 1995, Cohen et al. 1996, Petersenn et al. 1998). In addition, Pit-1 has been shown to activate the human GHS-R promoter (Petersenn et al. 2001). In order to determine if the stimulatory actions of glucocorticoids and the inhibitory actions of FFA, insulin and IGF-I on somatotrope function observed in the current report occur in parallel with changes in Pit-1 expression, the direct effects of these metabolic factors on Pit-1 mRNA levels were examined. As shown in Fig. 6, Pit-1 mRNA levels were not significantly altered by any of the factors tested. The lack of an effect of HY on Pit-1 expression is consistent with previous reports showing that DEX could increase GH mRNA levels without altering Pit-1 mRNA levels in cultures prepared from human GH-producing pituitary adenomas (Lloyd et al. 1993) and fetal (embryonic day 19) rat pituitaries (Nogami et al. 1999). Soto et al. (1995) demonstrated Pit-1 mRNA levels can be upregulated by GHRH, forskolin (a direct activator of adenylate cyclase) or 12O-tetradecanoyl phorbol-13-acetate (a direct activator of 

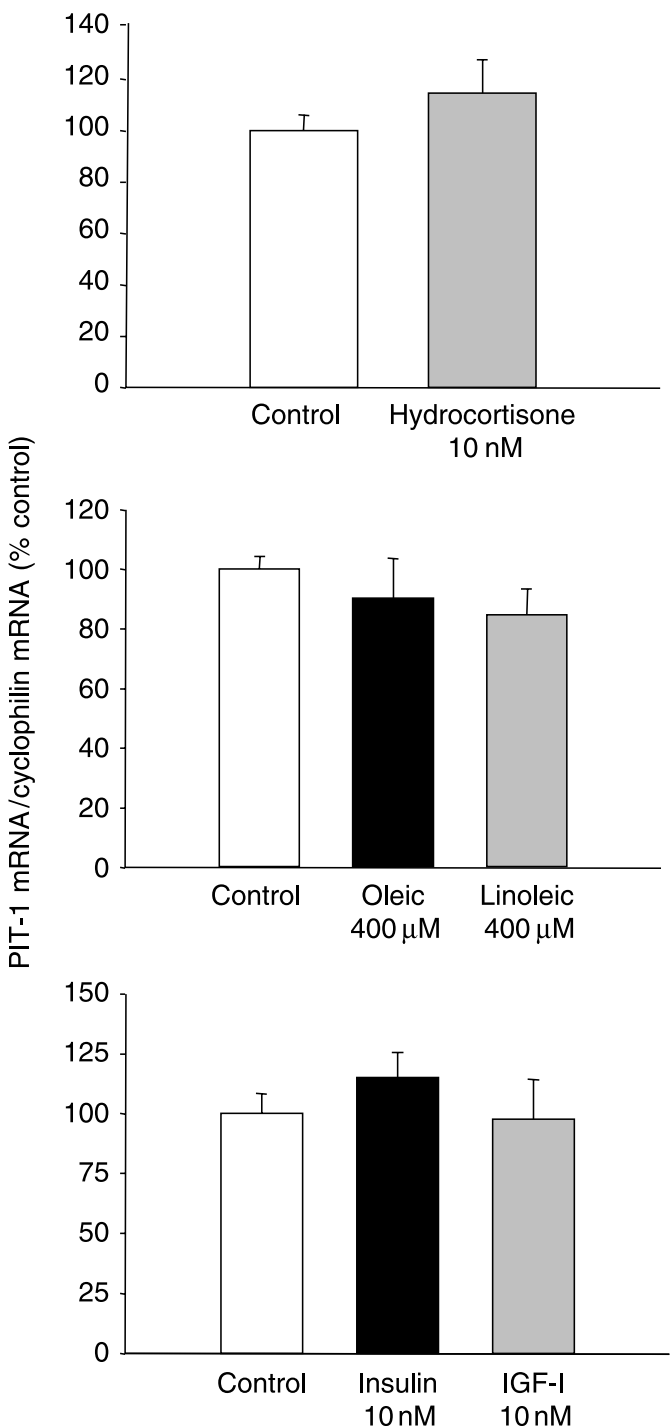

Figure 6 Effect of hydrocortisone $(10 \mathrm{nM})$, oleic and linoleic acid $(400 \mu \mathrm{M}$ each), insulin (10 nM) and IGF-I (10 nM) treatment (24 h) on pituitary-specific transcription factor-1 (Pit-1) mRNA levels in primary baboon pituitary cell cultures. Pit-1 mRNA copy number was determined by quantitative real-time RT-PCR and adjusted by cyclophilin A mRNA copy number as a housekeeping gene. All values are expressed as percent of vehicle-treated controls (set at $100 \%$ ) and represent the mean \pm S.E.M. of $3-5$ independent experiments (3-4 wells/treatment per experiment).

protein kinase $\mathrm{C}$ ) in primary rat pituitary cell cultures and this effect could be blocked by 48 -h pretreatment with IGF-I. However, consistent with the current observations, Soto et al. (1995) reported that IGF-I alone had no effect on Pit-1 expression. Likewise, Voss et al. (2000) demonstrated that exposure of $\mathrm{MtT} / \mathrm{S}$ cells (a rat pituitary cell line) to IGF-I effectively suppressed GH mRNA levels, but did not affect Pit-1 expression. In contrast, Chowen et al. (1998), using in situ hybridization for detection of Pit-1 mRNA coupled with immunocytochemistry for GH or prolactin, demonstrated that IGF-I (4 h) suppressed Pit-1 expression in lactotropes from primary pituitary cell cultures of female rats, while IGF-I had no effect on Pit-1 expression in male lactotropes or somatotropes from either gender. Castrillo and Aranda (1997) also reported that IGF-I could suppress both Pit-1 protein and mRNA levels in the rat pituitary cell line GH3, but IGF-I was not effective in regulating Pit-1 expression in a closely related cell line, GH4C1. These variable results indicate that regulation of Pit-1 expression is cell type-specific and may vary depending on the duration of exposure to the test substance. Nonetheless, we can conclude from the current observations that the effects of glucocorticoid, FFA, insulin or IGF-I on GH, GHRH-R and GHS-R expression in baboon primary pituitary cell cultures do not involve alterations in Pit-1 mRNA production or stability. However, we cannot exclude the possibility that Pit-1 protein levels may be modified in response to treatment. Unfortunately, in this study, limited sample number and size precludes the investigation of these factors at the protein level (i.e. via western blot analysis) at this time.

\section{Possible interactions of metabolic signals on direct regulation of somatotrope expression}

This report takes the path of reductionism and focuses on the isolated and direct effects of glucocorticoids, FFA, insulin and IGF-I on primate somatotrope function. However, in vivo, the pituitary is simultaneously exposed to all of these systemic metabolic factors (albeit at variable concentrations), in addition to receiving pulsatile stimulatory (GHRH) and inhibitory (SST) input from the hypothalamus. Exactly how these factors may interact at the pituitary level to ultimately modulate $\mathrm{GH}$ synthesis and release in metabolic extremes requires further investigation. However, based on the in vitro results showing that glucocorticoids enhance, while insulin and IGF-I suppress GH release and GH, GHRH-R and GHS-R mRNA levels, we might speculate that the rise in glucocorticoids and fall in insulin and IGF-I may be directly responsible for the increase in circulating $\mathrm{GH}$ levels, as well as the enhanced sensitivity to GHRH, observed in anorexia nervosa and fasting (Sugihara et al. 1996, Gianotti et al. 1999). Given the fact that FFA levels also rise in catabolic states, but are shown to directly suppress somatotrope function, serves to lessen their contribution in modulating GH output under these conditions. However, the inhibitory effects of FFA may play a more dominant role in obesity, working in conjunction with elevated insulin and IGF-I to directly suppress GH synthesis, as well as GH release in response 
to GH secretagogs (Maccario et al. 1994, Scacchi et al. 1999, Weltman et al. 2001, Cordido et al. 2003, Qu et al. 2004, Haijma et al. 2005). These results also suggest that, in vivo, the interspecies (rat vs human) differences in metabolic regulation of the $\mathrm{GH}$ axis are not due to differences in the response of the somatotrope to metabolic signals, but more likely reflect species differences in central integration of metabolic cues.

\section{Acknowledgements}

We would like to acknowledge the invaluable help of the veterinarian staff of the University of Illinois at Chicago, Biological Resource Center, with special thanks to Dr Lisa Haliday for facilitating the collection of the baboon tissues used in this study. This work was supported by the Secretaria de Universidades, Investigación y Tecnología de la Junta de Andalucia (to R M L), Endocrine Society Summer Fellowship Award (to M D G) and NIH NIDDK 30677 (to R D K). The authors declare that there is no conflict of interest that would prejudice the impartiality of this scientific work.

\section{References}

Aleppo G, Moskal SF 2nd, DeGrandis PA, Kineman RD \& Frohman LA 1997 Homologous down-regulation of growth hormone-releasing hormone receptor mRNA levels. Endocrinology 138 1058-1065.

Alvarez CV, Mallo F, Burguera B, Cacicedo L, Dieguez C \& Casanueva FF 1991 Evidence for a direct pituitary inhibition by free fatty acids of in vivo growth hormone responses to growth hormone-releasing hormone in the rat. Neuroendocrinology 53 185-189.

Andersen B \& Rosenfeld MG 2001 POU domain factors in the neuroendocrine system: lessons from developmental biology provide insights into human disease. Endocrine Reviews 22 2-35.

Bajai M, Suraamornkul S, Romanelli A, Cline GW, Mandarino LJ, Shulman GI \& DeFronzo RA 2005 Effect of a sustained reduction in plasma free fatty acid concentration on intramuscular long-chain Acyl-CoAs and insulin action in type 2 diabetic patients. Diabetes $\mathbf{5 4}$ 3148-3153.

Barkan AL, Demott-Friberg R \& Samuels MH 2000 Growth hormone (GH) secretion in primary adrenal insufficiency: effects of cortisol withdrawal and patterned replacement on GH pulsatility and circadian rhythmicity. Pituitary 3 175-179.

Brent GA, Harney JW, Moore DD \& Larsen PR 1988 Multihormonal regulation of the human, rat, and bovine growth hormone promoters: differential effects of $3^{\prime}, 5^{\prime}$-cyclic adenosine monophosphate, thyroid hormone, and glucocorticoids. Molecular Endocrinology 2 792-798.

Burguera B, Frank DH, DiMarchi R, Long S \& Caro JF 1991 The interaction of proinsulin with the insulin-like growth factor-I receptor in human liver, muscle, and adipose tissue. Journal of Clinical Endocrinology and Metabolism 72 1238-1241.

Caro JF, Poulos J, Ittoop O, Pories WJ, Flickinger EG \& Sinha MK 1988 Insulin-like growth factor I binding in hepatocytes from human liver, human hepatoma, and normal, regenerating, and fetal liver. Journal of Clinical Investigation 81 976-981.

Casanueva FF, Villanueva L, Dieguez C, Diaz Y, Cabranes JA, Szoke B, Scanlon MF, Schally AV \& Fernandez-Cruz A 1987 Free fatty acids block growth hormone $(\mathrm{GH})$ releasing hormone-stimulated $\mathrm{GH}$ secretion in man directly at the pituitary. Journal of Clinical Endocrinology and Metabolism 65 634-642.

Casanueva FF, Burguera B, Muruais C \& Dieguez C 1990 Acute administration of corticoids: a new and peculiar stimulus of growth hormone secretion in man. Journal of Clinical Endocrinology and Metabolism 70 234-237.

Castrillo AI \& Aranda A 1997 Differential regulation of pituitaryspecific gene expression by insulin-like growth factor 1 in rat pituitary GH4C1 and GH3 cells. Endocrinology 138 5442-5451.

Chowen JA, Gonzalez-Parra S, Garcia-Segura LM \& Argente J 1998 Sexually dimorphic interaction of insulin-like growth factor (IGF)-I and sex steroids in lactotrophs. Journal of Neuroendocrinology 10 493-502.

Cohen LE, Wondisford FE \& Radovick S 1996 Role of Pit-1 in the gene expression of growth hormone, prolactin and thyrotropin. Endocrinology and Metabolism Clinics of North America 25 523-540.

Cordido F, Alvarez-Castro P, Isidro ML, Casanueva FF \& Dieguez C 2003 Comparison between insulin tolerance test, growth hormone (GH)-releasing hormone (GHRH), GHRH plus acipimox and GHRH plus GH-releasing peptide-6 for the diagnosis of adult GH deficiency in normal subjects, obese and hypopituitary patients. European Journal of Endocrinology 149 117-122.

Dieguez C, Mallo F, Senaris R, Pineda J, Martul P, Leal-Cerro A, Pombo M \& Casanueva FF 1996 Role of glucocorticoids in the neuroregulation of growth hormone secretion. Journal of Pediatric Endocrinology and Metabolism 9 (suppl 3) 255-260.

Evans RM, Birnberg NC \& Rosenfeld MG 1982 Glucocorticoid and thyroid hormones transcriptionally regulate growth hormone gene expression. PNAS 79 7659-7663.

Frystyk J 2004 Free insulin-like growth factors-measurements and relationships to growth hormone secretion and glucose homeostasis. Growth Hormone and IGF Research 14 337-375.

Gianotti L, Rolla M, Arvat E, Belliti D, Valleto MR, Ferdeghini M, Ghigo E \& Mueller EE 1999 Effect of somatostatin infusion on the somatotrope responsiveness to growth hormone-releasing hormone in patients with anorexia nervosa. Biological Psychiatry $\mathbf{4 5}$ 334-339.

Goodyer CG, Marcovitz S, Hardy J, Lefebvre Y, Guyda HJ \& Posner BI 1986 Effect of insulin-like growth factors on human foetal, adult normal and tumour pituitary function in tissue culture. Acta Endocrinology 112 49-57.

Haijma SV, van Dam PS, de Vries WR, Maitimu-Smeele I, Dieguez C, Casanueva FF \& Koppeschaar HP 2005 The GHRH/GHRP-6 test for the diagnosis of GH deficiency in elderly or severely obese men. European Journal of Endocrinology 152 575-580.

Ho KY, Veldhuis JD, Johnson ML, Furlanetto R, Evans WS, Alberti KGMM \& Thorner MO 1988 Fasting enhances growth hormone secretion and amplifies the complex rhythms of growth hormone secretion in man. Journal of Clinical Investigation $\mathbf{8 1}$ 968-975.

Isaacs RE, Findell PR, Mellon P, Wilson CB \& Baxter JD 1987 Hormonal regulation of expression of the endogenous and transfected human growth hormone gene. Molecular Endocrinology 1 $569-576$.

Iwasaki Y, Morishita M, Asai M, Onishi A, Yoshida M, Oiso Y \& Inoue K 2003 Effects of hormones targeting nuclear receptors on transcriptional regulation of growth hormone gene in the $\mathrm{MtT} / \mathrm{S}$ rat somatotrope cell line. Neuroendocrinology 79 229-236.

de Jongh RT, Serne EH, Ijzerman RG, de Vries G \& Stehouwer CDA 2004 Free fatty acid levels modulate microvascular function: relevance for obesity-associated insulin resistance, hypertension, and microangiopathy. Diabetes 53 2873-2882.

Kamegai J, Tamura H, Shimizu T, Ishii S, Sugihara H \& Oikawa S 2005 Insulin-like growth factor-I regulates ghrelin receptor (growth hormone secretagogue receptor) expression in the rat pituitary. Regulatory Peptides 127 203-206. 
Kennedy JA, Nicolson R \& Welby ML 1994 The effect of oleic acid on the secretion of thyrotrophin and growth hormone by cultured rat anterior pituitary cells. Journal of Endocrinology 143 557-564.

Kok P, Buijs AA, Kok SW, van Ierssel IHAP, Frolich M, Roelfsema F, Voshol PJ, Meinders AE \& Pijl H 2004 Acipimox enhances spontaneous growth hormone secretion in obese women. American Journal of Physiology; Regulatory and Integrative Comparative Physiology 286 R693-R698.

Lloyd RV, Jin L, Chandler WF, Horvath E, Stefaneanu L \& Kovacs K 1993 Pituitary specific transcription factor messenger ribonucleic expression in adenomatous and nontumorous human pituitary tissues. Laboratory Investigations $69570-575$.

Luque RM \& Kineman RD 2006 Impact of obesity on the growth hormone axis: evidence for a direct inhibitory effect of hyperinsulinemia on pituitary function. Endocrinology 147 2754-2763.

Maccario M, Procopio M, Loche S, Cappa M, Martina V, Camanni F \& Ghigo E 1994 Interaction of free fatty acids and arginine on growth hormone secretion in man. Metabolism 43 223-226.

Martinoli MG, Veilleux R \& Pelletier G 1991 Effects of triiodothyronine, dexamethasone and estradiol-17 beta on GH mRNA in rat pituitary cells in culture as revealed by in situ hybridization. Acta Endocrinology 124 83-90.

Mayo KE, Godfrey PA, Suhr ST, Kulik DJ \& Rahal JO 1995 Growth hormone-releasing hormone: synthesis and signaling. Recent Progress in Hormone Research 50 35-73.

Melmed S, Yamashita S, Yamasaki H, Fagin J, Namba H, Yamamoto H, Weber M, Morita S, Webster J \& Prager D 1996 IGF-I receptor signalling: lessons from the somatotroph. Recent Progress in Hormone Research 51 189-215.

Mercado M \& Baumann G 1995 Characteristics of the somatotropic axis in insulin dependent diabetes mellitus. Archives of Medical Research 26 101-109.

Miller TL \& Mayo KE 1997 Glucocorticoids regulate pituitary growth hormone-releasing hormone receptor messenger ribonucleic acid expression. Endocrinology 138 2458-2465.

Morita S, Yamashita S \& Melmed S 1987 Insulin-like growth factor I action in rat anterior pituitary cells: effects of intracellular messengers on growth hormone secretion and messenger ribonucleic acid levels. Endocrinology 121 2000-2006.

Nakae J, Kido Y \& Accili D 2001 Distinct and overlapping functions of insulin and IGF-I receptors. Endocrine Reviews 22 818-835.

Nakagawa K, Akikawa K, Matsubara M \& Kubo M 1985 Effect of dexamethasone on growth hormone $(\mathrm{GH})$ response to growth hormone releasing hormone in acromegaly. Journal of Clinical Endocrinology and Metabolism 60 306-310.

Nam SY, Lee, Kim KR, Lee HC, Nam MS, Cho JH \& Huh KB 1996 Long-term administration of acipimox potentiates growth hormone response to growth hormone-releasing hormone by decreasing serum free fatty acid in obesity. Metabolism 45 594-597.

Niiori-Onishi A, Iwasaki Y, Mutsura N, Oiso Y, Inoue K \& Saito H 1999 Molecular mechanisms of the negative effect of insulin-like growth factor-I on growth hormone gene expression in $\mathrm{MtT} / \mathrm{S}$ somatotroph cells. Endocrinology 140 344-349.

Nogami H, Inoue K, Moriya H, Ishida A, Kobayashi S, Hisano S, Katayama M \& Kawamura K 1999 Regulation of growth hormonereleasing hormone receptor messenger ribonucleic acid expression by glucocorticoids in MtT-S cells and in the pituitary gland of fetal rats. Endocrinology 140 2763-2770.

Oosterom R, Verleun T \& Lamberts SW 1984 Human growth hormone-secreting pituitary adenoma cells in long-term culture: effects of dexamethasone and growth hormone releasing factor. Journal of Endocrinology 100 353-360.

Paek I \& Axel R 1987 Glucocorticoids enhance stability of human growth hormone mRNA. Molecular and Cellular Biology 7 14961507.
Park S, Sohn S \& Kineman RD 2004 Fasting-induced changes in the hypothalamic-pituitary-GH axis in the absence of GH expression: lessons from the spontaneous dwarf rat. Journal of Endocrinology 180 369-378.

Pérez FR, Camiña JP, Zugaza JL, Lage M, Casabiell X \& Casanueva FF 1997 cis-FFA do not alter membrane depolarization but block $\mathrm{Ca}^{2+}$ influx and GH secretion in KCl-stimulated somatotroph cells, Suggestion for a direct cis-FFA perturbation of the $\mathrm{Ca}^{2+}$ channel opening. Biochimica Biophysica Acta 1329 269-277.

Pérez FM, Camiña JP, Menendez C, Beiras A, Casabiell X \& Casanueva FF 1998 cis-unsaturated free fatty acids block VIP-mediated GH and PRL secretion by perturbing the cAMP/protein kinase A pathway. Pituitary 1 25-32.

Petersenn S, Rasch AC, Heyens M \& Schulte HM 1998 Structure and regulation of the human growth hormone-releasing hormone receptor gene. Molecular Endocrinology 12 233-247.

Petersenn S, Rasch AC, Penshorn M \& Beil FU 2001 Genomic structure and transcriptional regulation of human growth hormone secretagogue receptor. Endocrinology 142 2649-2659.

Qu X-D, Gaw Gonzalo IT, Al Syed MY, Cohan P, Christenson PD, Swerdloff RS, Kelly DF \& Wang C 2004 Influence of body mass index and gender on growth hormone $(\mathrm{GH})$ responses to GH-releasing hormone plus arginine and insulin tolerance tests. Journal of Clinical Endocrinology and Metabolism 90 1563-1569.

Richieri GV \& Kleinfeld AM 1995 Unbound free fatty acid levels in human serum. Journal of Lipid Research 36 229-240.

Rosenfeld RG, Ceda G, Wilson DM, Dollar LA \& Hoffman AR 1984 Characterization of high affinity receptors for insulin-like growth factors I and II on rat anterior pituitary cells. Endocrinology 114 $1571-1575$.

Scacchi M, Pincelli AI \& Cavagnini F 1999 Growth hormone in obesity. International Journal of Obesity and Related Metabolic Disorders 23 260-271.

Scacchi M, Pincelli AI \& Cavagnini F 2003 Nutritional status in the neuroendocrine control of growth hormone secretion: the model of anorexia nervosa. Frontiers in Neuroendocrinology 24 200-224.

Sector AA, John K \& Fletcher JE 1969 Binding of long-chain fatty acids to bovine serum albumin. Journal of Lipid Research 10 56-67.

Sjogren K, Liu J-L, Blad K, Skrtic S, Vidal O, Wallenius V, LeRoith D, Tornell J, Isaksson OG, Jansson JO \& Ohlsson C 1999 Liver-derived insulin-like growth factor I (IGF-I) is the principal source of IGF-I in blood but is not required for postnatal body growth in mice. PNAS 96 7088-7092.

Slater EP, Rabenau O, Karin M, Baxter JD \& Beato M 1985 Glucocorticoid receptor binding and activation of a heterologous promoter by dexamethasone by the first intron of the human growth hormone gene. Molecular and Cellular Biology 5 2984-2992.

Soto JL, Castrillo JL, Dominguez F \& Dieguez C 1995 Regulation of the pituitary-specific transcription factor GHF-1/Pit-1 messenger ribonucleic acid levels by growth hormone-secretagogues in rat anterior pituitary cells in monolayer culture. Endocrinology 136 3863-3870.

Spindler SR, Mellon SH \& Baxter JD 1982 Growth hormone gene transcription is regulated by thyroid and glucocorticoid hormones in cultured rat pituitary tumour cells. Journal of Biological Chemistry 257 11627-11632.

Strobl JS, Van Eys GJ \& Thompson EB 1989 Dexamethasone control of growth hormone mRNA levels in GH3 pituitary cells is cycloheximide-sensitive and primarily posttranscriptional. Molecular and Cellular Endocrinology 66 71-82.

Sugihara H, Emoto N, Shibasaki T, Minami S \& Wakabayashi I 1996 Increased pituitary growth hormone-releasing factor (GRF) receptor messenger ribonucleic acid expression in food-deprived rats. Brain Research 742 355-358.

Sugihara H, Emoto N, Tamura H, Kamegai J, Shibasaki T, Minami S \& Wakabayashi I 1999 Effect of insulin-like growth factor-I on growth hormone-releasing factor receptor expression in primary rat anterior pituitary cell culture. Neuroscience Letters 276 87-90. 
Tamaki M, Sato M, Matsubara S, Wada Y \& Takahara J 1996 Dexamethasone increases growth hormone $(\mathrm{GH})$-releasing hormone (GRH) receptor mRNA levels in cultured rat anterior pituitary cells. Journal of Neuroendocrinology 8 475-480.

Tamura H, Kamegai J, Sugihara H, Kineman RD, Frohman LA \& Wakabayashi I 2000 Glucocorticoids regulate pituitary growth hormone secretagogue receptor gene expression. Journal of Neuroendocrinology 12 481-485.

Tannenbaum GS, Martin JB \& Colle E 1976 Ultradian growth hormone rhythm in the rat: effects of feeding, hyperglycemia, and insulin-induced hypoglycemia. Endocrinology 99 720-727.

Tannenbaum GS, Rorstad O \& Brazeau P 1979 Effects of prolonged food deprivation on the ultradian growth hormone rhythm and immunoreactive somatostatin tissue levels in the rat. Endocrinology 104 1733-1738.

Voss TC, Mangin TM \& Hurley DL 2000 Insulin-like growth factor-I causes a switch-like reduction of endogenous growth hormone mRNA in rat MtT/S somatotorph cells. Endocrine 13 71-79.

Voss TC, Flynn MP \& Hurley DL 2001 IGF-I causes an ultrasensitive reduction in GH mRNA levels via an extracellular mechanism involving IGF binding proteins. Molecular Endocrinology 15 1549-1558.

Wallenius K, Sjogren K, Peng X-D, Park S, Wallenius V, Liu J-L, Umaerus M, Wennbo H, Isaksson O, Frohman LA, Kineman RD, Ohlsson C \& Jansson J-O 2002 Liver-derived IGF-I regulates growth hormone (GH) secretion at the pituitary level in mice. Endocrinology 142 117-1123.
Weltman A, Weltman JY, Veldhuis JD \& Hartman ML 2001 Body composition, physical exercise, growth hormone and obesity. Eating and Weight Disorders 6 (suppl 3) 28-37.

Yakar S, Liu JL, Stannard B, Butler A, Accili D, Sauer B \& LeRoith D 1999 Normal growth and development in the absence of hepatic insulin-like growth factor I. PNAS 96 7324-7329.

Yamashita S \& Melmed S $1986 a$ Effects of insulin on rat anterior pituitary cells: Inhibition of growth hormone secretion and mRNA levels. Diabetes 35 440-447.

Yamashita S \& Melmed S $1986 b$ Insulin regulation of rat growth hormone gene transcription. Journal of Clinical Investigation $\mathbf{7 8}$ $1008-1014$

Yamashita S \& Melmed S 1986c Insulin-like growth factor I action on rat anterior pituitary cells: suppression of growth hormone secretion and messenger ribonucleic acid levels. Endocrinology 118 $176-182$.

Yamashita S \& Melmed S 1987 Insulin-like growth factor I regulation of growth hormone gene transcription in primary rat pituitary cells. Journal of Clinical Investigation 79 449-452.

Yamashita S, Weiss M \& Melmed S 1986 Insulin-like growth factor I regulates growth hormone secretion and messenger ribonucleic acid levels in human pituitary tumor cells. Journal of Clinical Endocrinology and Metabolism 63 730-735.

Received in final form 23 March 2006

Accepted 3 April 2006 